\title{
Plagiatlıqla mübarizə informasiya təhlükəsizliyinin mühüm komponenti kimi
}

\author{
Rasim Oliquliyev ${ }^{1}$, Ramiz Alıquliyev ${ }^{2}$, Rasim Mahmudov $^{3}$ \\ ${ }^{1,2}$ AMEA İnformasiya Texnologiyaları İnstitutu, Bakı, Azərbaycan \\ ${ }^{1}$ r.alguliev@gmail.com, ${ }^{2}$ r.aliguliyev@gmail.com, ${ }^{3}$ rasimmahmudovegmail.com
}

\begin{abstract}
Xülasə - Məqalədə müəllif hüququnun pozulmasının xüsusi halı olan plagiatlıqla mübarizənin informasiya təhlükəsizliyinin mühüm istiqaməti olduğu əsaslandırılmışdır. Azərbaycanda plagiatlıqla mübarizəyə dair təkliflər irəli sürülmüşsür. Bunun üçün zəruri olan milli elektron kontentin formalaşdırılmasının, milli antiplagiat sisteminin yaradılmasının konseptual əsasları işlənmişdir. Plagiatlıqla mübarizənin hüquqi, ictimai qınaq və maarifləndirmə metodlarının tətbiqinə dair tövsiyələr verilmişdir.
\end{abstract}

Açar sözlor- müallif hüququ, plagiat, milli antiplagiat sistemi, milli kontent.

\section{GİİŞ}

İnformasiya cəmiyyətində informasiya və bilik əsas strateji məhsula, maddi sərvətlərin formalaşmasının əsas mənbəyinə çevrilir. Yeni iqtisadiyyatda innovasiyaların, yaradıcı əməyin, intellektual mülkiyyətin, informasiya məhsullarının rolu sürətlə artır. Belə bir şəraitdə intellektual mülkiyyətin və onun əsas tərkib hissəsi olan müəllif hüquqlarının qorunması məsələsi informasiya təhlükəsizliyinin mühüm vəzfifələrindən biri kimi xüsusi aktuallıq kəsb edir.

Müəllif hüququ elm, ədəbiyyat və incəsənət əsərlərinin yaradılması və istifadəsi sahəsində ictimai münasibətləri tənzimləyir. Müəllif hüququnun obyektləri müxtəlif növ informasiya məhsullarıdır. İnformasiyua təhlükəsizliyinin mühüm vəzifələrindən biri də məhz informasiya məhsulları ilə bağlı sahiblik, istifadə və sərəncam hüquqlarının qorunmasıdır [1].

Müəllif hüququnun pozulmasının ənənəvi formalarından biri plagiatlıqdır. İnternetin meydana gəlməsi, mətnlərin rəqəmsallaşması, nüsxələmənin asanlaşması plagiatlıq problemini daha da kəskinləşdirmişdir. Hazırda plagiatlıq tələbələr, elmi tədqiqatçılar, ədiblər, jurnalistlər, musiqiçilər və digər incəsənət nümayəndələri arasında geniş yayılmışdır. Xüsusilə, elmi fəaliyyət sahəsində bu problem özünü daha qabarıq şəkildə büruzə verir.

Hüquqi ədəbiyyatda plagiat dedikdə, başqalarına məxsus ədəbiyyat, incəsənət və elmi əsərlərin, ixtiraların və $\mathrm{s}$. intellektual yaradicılıq məhsullarının bilərəkdən mənimsənilməsi başa düşülür. Lakin müəyyən qaydalara əməl etməklə ideyalardan, konsepsiyalardan, metodlardan və $\mathrm{s}$. müəllif hüququ obyektlərindən istifadə edilməsi plagiatlıq sayılmir.
Plagiatlıq hallarının qarşısının alınması üçün mənəvi-etik, hüquqi, texnoloji, maarifləndirici və s. tədbirlərin görülməsi zəruridir. İKT-nin köməyi ilə İnternet mühitində baş verən plagiatlıq halları ilə mübarizə üçün yeni üsul və vasitələr tələb edilir. Antiplagiat proqramları İnternet mühitində olan materiallar əsasında müvafiq halların aşkarlanması üçün ən yaxşı vasitədir. Lakin plagiatlıq hallarında istinad edilən bir sıra elmi əsərlər vardır ki, onların elektron versiyaları yoxdur. Ona görə də müvafiq proqramlar vasitəsi ilə heç də bütün plagiatlıq hallarını üzə çıxarmaq mümkün olmur. Bu da milli elektron elmi kontentin yaradılması məsələsini aktuallaşdırır [2].

Ölkəmizdə İnternetdən istifadə imkanlarının artması, əhali arasında ingilis və digər xarici dil biliklərinin səviyyəsinin yüksəlməsi plagiatlıq üçün əlverişli şərait yaradır.

Plagiatliq cəmiyyətin və dövlətin informasiya təhlükəsizliyinə ciddi təhdiddir. Belə ki, cəmiyyətdə plagiatlıq hallarının artması əhali arasında informasiya mədəniyyətinin, insanların informasiya təhlükəsizliyinə qarşı dözümsüzlük səviyyəsini aşağı salır.

İnformasiya mədəniyyəti səviyyəsinin aşağı olması, müxtəlif mənbələrdən müstəqil şəkildə informasiya toplamaq, müqayisə və analiz etmək, daha mötəbər, aktual informasiyanı müəyyənləşdirmək bacarığının olmaması, əhalinin dezinformasiyaya qarşı həssas olmasına gətirib çıxardır. Ona görə də plagiatlıqla mübarizəyə müəllif hüququnun, intellektual mülkiyyətin qorunması ilə yanaşı, həm də, daha geniş mənada, informasiya təhlükəsizliyinin qorunması məsələsi kimi baxmaq lazımdır.

\section{INTERNET MÜHITTINDӘ MILLİ KONTENTIN FORMALAŞDIRILMASI MOSOLӘLORİ}

Plagiatlıq hallarının aşkar olunmasının əsas şərtlərindən biri İnternet mühitində milli kontentin formalaşdırılmasıdır. Belə ki, şəffaflıq və əlyetərlilik plagiatlıq imkanlarını minimuma endirir. Eyni zamanda, rəqəmsal formada olan mətnlərdə plagiatlıq elementlərini texnoloji üsullarla aşkarlamaq daha asandır. Ona görə də İnternet mühitində milli kontentin formalaşdırılması bir sıra amillərlə yanaşı, plagiatlıqla effektli mübarizə aparmaq baxımından da aktuallıq kəsb edir [2]. 


\section{“Informasiya tohlükosizliyinin aktual multidissiplinar elmi-praktiki problemlori” IV respublika konfransı, 14 dekabr 2018-ci il}

Hazırda ölkənin müxtəlif təyinatlı və səviyyəli kitabxanalarında, arxivlərində saxlanılan materialların (kitablar, jurnallar, dissertasiyalar və s.) əksəriyyəti kompüterləşmə dövründən əvvəl çap olunduğuna görə onların elektron versiyaları mövcud deyil. Həmin materialların rəqəmsal formaya keçirilməsi çox vacibdir. $\mathrm{Bu}$, genişmiqyaslı, yüksək əmək və maliyyə tutumlu iş olduğuna görə, dünyanın bir çox ölkələrində müvafiq prosesi effektli şəkildə həyata keçirmək üçün xüsusi dövlət proqramlarının həyata keçirilməsi təcrübəsi vardır.

Ölkə üzrə müxtəlif qurumların tabeliyində olan ekitabxanaların əksəriyyətinə İnternet vasitəsi ilə daxil olmaq mümkün deyildir. Baxmayaraq ki, “Azərbaycan Respublikasında informasiya cəmiyyətinin inkişafina dair 2014-2020-ci illər üçün Milli Strategiya"da "kitabxana, arxiv və muzeylərdə İKT-nin tətbiqinin, elektron kitabxana şəbəkəsinin genişləndirilməsi” məsələsi öz əksini tapmışdır, bu problem həll edilməyib [3].

Bundan başqa, müxtəlif nəşriyyatlar tərəfindən çap olunan kitabların e-versiyaları, əsasən, onlayn mühitdə deyildir. Elmi jurnalların əksəriyyətinin veb-saytları müasir beynəlxalq standartlara, nüfuzlu axtarış sistemlərinin tələblərinə cavab vermir. Ona görə də İnternetdə axtarış apararkən həmin jurnallarda yerləşdirilən məqalələri əldə etmək mümkün olmur.

Müəssisələrin sərəncamında olan çap materiallarının rəqəmləşdirilməsi, etibarlı saxlanılması, istismarı, arxivləşdirilməsi, onlayn mühitdə əlyetərliyinin təmin olunması və s. kimi məsələlər məsul şəxslərin qarşısında ciddi bir vəzifə kimi qoyulmur. Bu işlərin həyata keçirilməsi, əsasən, könüllü xarakter daşıyır.

Bununla əlaqədar zəruri normativ-hüquqi sənədlər, standartlar və onların tətbiqini təmin edən inzibati mexanizmlər mövcud deyildir.

Qeyd edilən problemlərin aradan qaldırılması, yalnız çap şəklində olan ədəbiyyatın, kitabxanaların rəqəmləşdirilməsi və bütövlükdə, milli elektron kontentin inkişaf etdirilməsi üçün xüsusi dövlət proqramının həyata keçirilməsi zəruridir.

İlk növbədə, sərəncamlarında çap formasında ədəbiyyat olan müvafiq qurumların həmin materialları rəqəmli formaya keçirərək İnternet mühitində əlyetərliliyini təmin etmələri vacibdir. Bunun üçün isə yüksək imkanlara malik skanerlər və digər kompüter avadanlıqları ilə təchizat məsələsi həll olunmalidir.

Rəqəmləşdirilmiş materialların etibarlı saxlanılması, istifadəsi və arxivləşdirilməsi üçün müvafiq qurumların tərkibində fasiləsiz fəaliyyət göstərən Data-mərkəzlərin (verilənlərin saxlanılması mərkəzləri) təşkil edilməsi vacibdir. Müəssisələrdə mühüm əhəmiyyət kəsb edən informasiya resurslarının uçotu, etibarlı saxlanılması, istismarının təmin olunması və arxivləşdirilməsi, müvafiq Data-mərkəzlərə təhvil verilməsi üçün məsul şəxslər və onların hüquqi məsuliyyəti zəruri normativ-hüquqi sənədlərlə dəqiq müəyyənləşdirilməlidir.

Ölkə, dövlət qurumları və müəssisələr səviyyəsində informasiyalaşdırma proseslərini nəzarətdə saxlamaq, analiz etmək, qiymətləndirmək, müxtəlif təyinatlı monitorinqlər aparmaq məqsədi ilə iyerarxik qaydada bütün təşkilatlar üzrə xüsusi statistik formalar işlənilməli, müntəzəm olaraq həmin hesabatlar toplanılmalı və emal olunmalıdır. Bunun da əsasında müəssisələrin fəaliyyətinə qiymət verilməlidir.

Elmi jurnalların beynəlxalq tələblərə cavab verməyən vebsaytları, həmçinin arxivlərdə, çap şəklində olan jurnalları rəqəmləşdirərək İnternet mühitində əlyetərliyi təmin olunmayana qədər Azərbaycan Respublikasının Prezidenti yanında Ali Attestasiya Komissiyası tərəfindən onların tanınması məqsədəuyğun sayılmamamlıdır.

Biznes qurumları tərəfindən çap olunan kommersiya xarakterli materialların onlayn mühitdə açıq istifadəsinin təmin olunması üçün dövlət tərəfindən müəyyən stimullaşdırıcı mexanizmlər işlənib tətbiq olunmalıdır.

\section{MILLİ ANTIPLAGİAT SISTEMININ YARADILMASINA DAIR KONSEPTUAL BAXIŞLAR}

Hal-hazırda ölkəmizdə xarici antiplagiat sistemlərindən (AS) pərakəndə şəkildə istifadə olunur və ümumiyyətlə, onların hər biri haqqında fikirlər, rəylər fərqlidir. Xarici ASdən asılılıq və kifayət qədər maliyyə resurslarının ölkədən kənara axını problemi vardır.

Plagiatlığa qarşı mübarizə mexanizmlərindən biri də elmi araşdırma prosesinin şəffaflığının təmin olunmasıdır. $\mathrm{Bu}$ məqsədlə Respublika üzrə elmi tədqiqatların koordinasiya şurası tərəfindən elektron elmin alt sistemləri olan "Elmi problemlər reyestri", "Dissertasiya mövzularının qeydiyyatı reyestri", "Elmi hesabatlar reyestri", "Doktorantlar və dissertantlar reyestri", "Elmi kadrlar reyestri" və s. kimi açıq onlayn informasiya resurslarının yaradılması və istismarını təmin etmok lazımdır.

Ekspertlərin qənaətinə görə, xarici AS-dən istifadə prosesində toplanmış məlumatların intellektual emalı əsasında hər hansı hədəf seçilmiş ölkədə elmin və təhsilin, tələbə və müəllimlərin, alimlərin mənəvi-etik, hüquq pozuntuları, dinamikası və s. xüsusiyyətləri haqqında analitik biliklər əldə etmək olar. Bu isə ölkənin təhlükəsizliyi üçün müəyyən risklər yaradir.

Xarici AS-dən istifadə zamanı milli maraqlar naminə çoxməqsədli analizlər aparmaq, qiymətləndirmək, tövsiyələr işləmək və səmərəli qərarlar qəbul etmək imkanları yoxdur. Bütün bunları nəzərə alaraq, hesab edirik ki, Milli antiplagiat sisteminin (MAS) yaradılması vo tətbiqi daha məqsədəuyğundur.

MAS-a e-dövlətin mühüm seqmentləri olan e-elm və etəhsilin tərkib hissəsi kimi baxmaq lazımdır. Belə ki, edövlətin əsas məqsədləri sırasında idarəçiliyin metod və mexanizmlərinin təkmilləşdirilməsi, səmərəliliyinin artırılması, hesabatlılığın və şəffaflığın təmin edilməsi kimi məsələlərdir. Elm və təhsil sistemlərində elmi fəaliyyətin şəffaflığının və hesabatlılığının təmin edilməsi, qiymətləndirilməsinin təkmilləşdirilməsi və səmərəliliyinin artırılması baxımından MAS effektli texnoloji vasitədir.

Müvafiq dünya təcrübəsinin analizinə əsasən, belə qənaətə gəlmək olar ki, hər hansı bir antiplagiat sisteminin yaradılması, 


\section{“Informasiya tohlükosizliyinin aktual multidissiplinar elmi-praktiki problemlori” IV respublika konfransı, 14 dekabr 2018-ci il}

sınaqdan keçirilməsi və təkmilləşdirilməsi üçün müəyyən müddət tələb edilir. Bu baxımdan, MAS-nin yaradılması və müəyyən keyfiyyət səviyyəsinə çatdırılması üçün müəyyən vaxt lazımdır. Ona görə də MAS effektli tətbiq üçün tam hazır olana qədər xarici AS-dən istifadə məqsədəuyğundur.

Ümumiyyətlə, ölkədə AS-in yaradılmasına dair mütəxəssislər arasında iki yanaşma vardır:

- xarici AS-ni Azərbaycan dilinin xüsusiyyətlərini nəzərə alaraq, müvafiq açıq informasiya resurslarını təkmilləşdirmək və geniş tətbiqini təmin etmək.

- beynəlxalq təcrübədən faydalanmaqla ölkənin intellektual, maliyyə və digər potensialı hesabına MAS-1 yaratmaq, istismarı və inkişafını təmin etmək.

MAS-nin yaradılması ilkin halda nisbətən böyük maliyyə resursları tələb etsə də, sonrakı dövrdə bu xərclər xeyli azalacaqdır. Ölkə daxilində vətəndaşlara çox aşağ1 qiymətə (yaxud da pulsuz) onlayn antiplagiat xidmətləri göstərilə bilər.

MAS yaradılarsa, sistemdə toplanmış məlumatlar əsasında elm və təhsil prosesi, ayr1-ayrı fərdlərin mənəvi-etik, hüquq pozuntuları barədə zəruri biliklər əldə olunacaq. Gələcəkdə təşkilatlar (elm, təhsil və s. müəssisələr) və şəxslər barəsində müxtəlif xarakterli qərarlar qəbul edilərkən plagiatlıq əməllərinin də nəzərə alınması məqsədəuyğundur.

Kitabxanalarda, arxivlərdə toplanan dissertasiyalar, monoqrafiyalar, jurnallar və s. rəqəmləşdirilərək İnternet mühitində yerləşdirildikdən sonra MAS elmi dərəcəsi olan şəxslərin dissertasiya işlərini, digər əsərlərini də yoxlayıb plagiatlıq əməllərini aşkarlayaraq ictimaiyyəti məlumatlandırmaq imkanına malik olacaqdır.

MAS tələbələrin, müəllim və alimlərin, digər bilik yaradıcılığı ilə məşğul olan şəxslərin müəllifi olduqları materiallarda aşkarlanmış plagiatlıq faktlarının qeydiyyatını, uçotunu aparıb sistemləşdirərək ayrı-ayrı şəxslər (alimlər, tələbələr və s.) və müəssisələr üzrə elektron plagiatlıq reyestrləri yaratmağa imkan verəcəkdir.

MAS istismara verildikdən sonra xarici ölkələrdəki bədniyyətli qüvvələrin ölkəmizdə formalaşan biliklər cəmiyyətinin, onun sosial seqmentləri (elm, təhsil müəssisələri və s.), həmçinin ayrı-ayrı vətəndaşların intellektual cinayətləri haqqında məlumat toplamaq və analitik biliklər əldə etmək imkanı olmayacaqdir.

MAS veb-platformasında kliyent/server texnologiyas əsasında fəaliyyət göstərəcək sosio-texnoloji infrastruktura malik bir sistem kimi istismar olunacaqdır. Bu sistem istismara verildikdən sonra qlobal səviyyədə, virtual məkanda plagiatlı̆ga qarşı səmərəli mübarizə aparmaq məqsədi ilə xarici ölkələrin AS-i, İnternetdə mövcud olan axtarış sistemləri ilə əməkdaşlıq münasibətləri qurula bilər.

MAS-nin konseptual, arxitektur-texnoloji əsaslarının işlənilməsi, toplanacaq informasiyanın intellektual analizi (Big Data analitikası), təhlükəsizliyinin təmin olunması, həssas fərdi məlumatların qorunması, mükəmməl kompüter tərcüməsi sistemlərinin işlənilməsi, dissertasiya və digər elmi əsərlərin müəlliflərinin identifikasiyası və $\mathrm{s}$. kimi elmi tutumlu problemlərin həlli üçün geniş tədqiqatlar aparılması, gənc kadrların yetişdirilməsi vacibdir.

MAS-nin yaradılması, istismarı və daim təkmilləşdirilməsi, inkişafı məqsədi ilə fəaliyyət planının işlənilməsinə ehtiyac vardır. Eyni zamanda, MAS-a dövlət əhəmiyyətli informasiya sistemi statusunun verilməsi və bu məqsədlə müvafiq normativ-hüquqi sənədlərin hazırlanması zəruridir.

MAS-ın yaradılması, istismarı və inkişafının dəstəklənməsi məqsədi ilə bütün mərhələlər üzrə həyata keçiriləcək işlərin maliyyələşdirilməsinə, eyni zamanda, xarici AS-in servislərindən istifadə etmək üçün elm və təhsil müəssisələrinə maliyyə dəstəyi göstərilməsinə ehtiyac vardır.

MAS-ın yaradılmasına dair fəaliyyət planında nəzərdə tutulmuş işlər, həmçinin maddi-texniki təminat üzrə texnikiiqtisadi araşdırmalar aparıb tələb olunan xərclər və onların maliyyələşdirilməsi üçün mənbələr müəyyənləşdirilməlidir.

\section{PLAGİATLIQLA HÜQUQİ MÜBARİZ YOLLARI}

Plagiatlıqla mübarizə metodlarından biri hüquqi mübarizədir. Müasir beynəlxalq hüquq təcrübəsində plagiatlıq müəllif hüququnun pozulması hallarından biri kimi qəbul olunur. Lakin Azərbaycanın bu sahədə ictimai münasibətləri tənzimləyən "Müəlliflik hüququ və əlaqəli hüquqlar haqqında" qanunda və "Oqli mülkiyyət hüquqlarının təminatı və piratçılığa qarşı mübarizə haqqında" qanunda plagiatlıqla bağlı məsələlər öz əksini tapmayıb [4, 5].

Azərbaycanda plagiatlıqla bağlı hüquqi baxımdan qeyrimüəyyənliklər mövcud olduğuna görə məhkəmələr tərəfindən bu qanun pozuntusuna görə qərar vermək çox çətindir. Ona görə də ölkəmizdə plagiatlıq əməllərinə hüquqi qiymətin veriməsi hallarına rast gəlinmir. Müvafiq qurumlarda da plagiatliq sahəsində beynəlxalq hüquqi təcrübənin öyrənilməsi istiqamətində elmi araşdırmalar aparılmır.

Plagiatlıqla effektli hüquqi mübarizə aparmaq üçün vacib olan məsələlərdən biri də müvafiq kadr təminatının həyata keşirilməsidir. Azərbaycan qanunvericiliyində plagiatlıqla mübarizə tədbirləri nəzərdə tutulmadığına görə, ölkəmizdə bu sahədə istintaq, məhkəmə-ekspertiza təcrübəsi də demək olar ki, mövcud deyil. Müvafiq ali məktəblərdə bu sahə üzrə mütəxəssislər də hazırlanmır. Ona görə də plagiatlığın elminəzəri, texniki, hüquqi, etik və s. aspektlərini əhatə edən biliklərə malik mütəxəssislər hazırlanmalıdır ki, onlar da, öz növbəsində, ali məktəblərdə müvafiq fənni tədris etsinlər.

Plagiatlıqla hüquqi mübarizəni çətinləşdirən əsas problemlərdən biri bu cür əməllərin qlobal xarakterli və ya miqyaslı olmasıdır. Yəni İnternetin yaratdığı qlobal virtual mühitdə plagiatlığı törədənlə plagiatlığa məruz qalan müxtəlif ölkələri təmsil edə bilərlər. Dünyanın ayrı-ayrı ölkələrində isə plagiatlığa münasibət fərqlidir. Bu problemdən çıxış yolu plagiatliqla mübarizə sahəsində xüsusi beynəlxalq konvensiyanın qəbul edilməsi və müvafiq qarşlıqlı hüquqi yardım haqqında ikitərəfli dövlətlərarası müqavilələrin bağlanmasıdır. 


\section{“Informasiya tohlükosizliyinin aktual multidissiplinar elmi-praktiki problemlori” IV respublika konfransı, 14 dekabr 2018-ci il}

\section{PLAGIAATLIQ ӘMӘLLӘRININ İCTIMAIILəŞDİRILMӘSİ MəSӘLӘLӘRI}

Plagiatlıqla effektli mübarizə üsullarından biri də bu cür əməllərin ictimailəşdirilməsi, ictimai qunaq obyektinə çevrilməsinin təşkildir. Cəmiyyətin aşağı təbəqələrini təmsil edən insanlar tərəfindən törədilən məişət xarakterli cinayət əməllərinə görə bu cür üsullardan istifadə edilməsi effektli nəticə vermir. Çünki belə şəxslərin itirəcəkləri ictimai nüfuzları, karyeraları yoxdur. Plagiat elmi iş ortaya qoyanlar isə, adətən, cəmiyyətin yüksək təbəqəsinə aid olan, müxtəlif karyera hədəfləri olan insanlar olur. Ona görə də plagiatlıq edən insanların bu əməllərinə görə rüsvay edilmələri olduqca böyük effekt verir.

Plagiatlıq əməlləri tam sübut olunduğu hallarda müvafiq dövlət qurumları tərəfindən ictimaiyyətə rəsmi məlumat verilməsi məqsədəuyğundur. Bundan sonra plagiatlığa əl atan şəxslər haqqında məlumatlar müntəzəm olaraq KIV-də, sosial media resurslarında yayıla bilər. Bu fəaliyyət ilə məşğul olan şəxslər ictimai qınaq, məzəmmət obyektinə çevrilməlidirlər.

Bu məqsədlə xüsusi portal (məsələn: www.plagiatayox.az) yaradıb plagiatlıq, səbəbləri, növləri, onunla mübarizə texnologiyaları, aşkarlanmış faktlar və s. kimi məlumatların ictimaiyyətə təqdim olunması məqsədəuyğundur. Həmçinin televiziya kanallarında, İnternet saytlarında, ictimai yerlərdə, elm-təhsil müəssisələrində plagiatlıqla mübarizə məqsədi daşıyan sosial reklam çarxları nümayiş etdirilməsi də effektli bir vasitədir.

$\mathrm{Bu}$ sahədə xarici ölkələrin qabaqcil təcrübəsinin öyrənilərək tətbiq edilməsi və həmin ölkələrin müvafiq qurumları ilə əməkdaşlıq münasibətlərinin qurulması zəruridir.

\section{PLAGİATLIQ VӘ ONUNLA MÜBARİZ YOLLARININ TODRİSI}

Plagiatlı̆̆ın baş vermə səbəblərindən biri də bu əməli törədənlərin onun barəsində məlumatsız olmalarıdır. Halhazırda ölkəmizdə plagiatlığın meydana gəlməsi səbəbləri, növləri, antiplagiat mexanizmləri, bu əməllərin yaratdığ 1 mənəvi-etik və hüquqi məsuliyyət və s. haqqında biliklər təhsilin heç bir pilləsində tədris olunmur.

Plagiatlığa qarșı mübarizə texnologiyaları, mexanizmləri, antiplagiat sistemləri haqqında hədəf auditoriyasına, ümumiyyətlə, vətəndaşlara zəruri biliklər verilməlidir Plagiatlıq əməllərinin yaratdığ 1 mənəvi-etik və hüquqi məsuliyyət haqqında vətəndaşlar maarifləndirilməlidirlər.

Azərbaycan dilində bu sahə üzrə dərsliklər və digər öyrədici vasitələr mövcud deyil, həmin bilikləri tədris edəcək müəllimlər də hazırlanmır. Magistratura və doktorantura təhsil səviyyələrində "Plagiatlıq və onunla mübarizə yolları" adı altında sistemli biliklərin tədris olunması vacibdir. Bunun üçünsə, ilk növbədə, dəsrliklər, metodiki vəsaitlər hazırlanmalı, müvafiq dərsləri tədris edəcək müəllimlər yetişdirilməlidir

\section{NӘTIC๐}

Beləlikla, belə nəticəyə gəlmək olar ki, plagiatlıqla mübarizəyə dair irəli sürülən ideyaların, konseptual baxışların aidiyyatı qurumların iștirakı ilə geniș müzakirə olunması və müəyyən bir konsensusun əldə edilməsi vacibdir. Müzakirələrin nəticəsi olaraq aiddiyyati qurumların mütəxəssisləri tərəfindən "Azərbaycan Respublikasında plagiatlığa qarşı mübarizə sahəsində milli fəaliyyət planı"nın işlənilməsinə ehtiyac vardır.

Milli fəaliyyət planında görüləcək işlər, vəzifələr, icraçılar, icra müddəti, maliyyə resurları müəyyənləşdirilməlidir. $\mathrm{Bu}$ planının icrasını təmin etmək məqsədi ilə icraçı qurumların məsul vəzifəli şəxslərindən ibarət Koordinasiya şurası və bu şuranın nəzdində müxtəlif problemlər (texnologiya, linqvistika, kontent, hüquq və s.) üzrə işçi qruplar təşkil olunmalıdır.

\section{ӘDӘBIYYAT}

[1] R.M.Oliquliyev, R.Ş Mahmudov, "İnformasiya cəmiyyətində intellektual mülkiyyət hüquqlarının qorunması problemləri”, İnformasiya cəmiyyəti problemləri, Bak1, 2015, №2, c. 4-14

[2] R.M.Oliquliyev, N.B.Ağayev, R.M.Alıquliyev, "Plagiatlıqla mübarizə texnologiyaları", Bakı, “Informasiya Texnologiyaları” nəşriyyatı, 2015, $165 \mathrm{~s}$

[3] "Azərbaycan Respublikasında informasiya cəmiyyətinin inkişafına dair 2014-2020-ci illər üçün Milli Strategiya", http:/president.az/articles/11312

[4] "Müəllif hüququ və əlaqəli hüquqlar haqqında" AR Qanunu, http://www.copat.gov.az

[5] Әqli mülkiyyət hüquqlarının təminatı və piratçılığa qarşı mübarizə haqqinda" AR Qanunu, http://www.copat.gov.az

\section{FIGHT AGAINST PLAGIARISM AS AN IMPORTANT} ASPECT OF INFORMATION SECURITY

Rasim M. Alguliyev ${ }^{1}$, Ramiz M. Aliguliyev ${ }^{2}$, Rasim Mahmudov $^{3}$

Institute of Information Technology of ANAS, Baku, Azerbaijan

${ }^{1}$ r.alguliev@gmail.com, ${ }^{2}$ r.aliguliyev@gmail.com, rasimmahmudov@gmail.com

Abstract - The article argues that the fight against plagiarism, which is a special case of copyright infringement, is an important aspect of information security. Proposals on fight against plagiarism in Azerbaijan are put forward. The conceptual basis for the formation of national electronic content and the creation of a national anti-plagiarism system is developed for this purpose. Recommendations on the application of legal, public awareness and awareness raising methods in the fight against plagiarism are provided. 